Research Article

\title{
The Representation of the City Branding of "Kampung Pesilat Indonesia" As Sports Tourism in the Madiun Regency
}

\author{
Toton Aristono $^{1}$, Sugiyanto ${ }^{2}$, Rony Syaifullah ${ }^{3}$ \\ ${ }^{123}$ Postgraduate in Sports Science, Sebelas Maret University, Indonesia
}

\begin{abstract}
The increasing competition between cities is the impact of globalization. A city musthave a promotion strategy as a regional attraction. Place marketing such as city branding is very important to be implemented to the competitiveness of cities and countries. The Indonesian Pesilat Village (Kampung Pesilat Indonesia) is a city branding of Madiun Regency, inaugurated in 2018. This shows the commitment of Madiun Regency to promote Pencak Silat as sports tourism through city branding. This study aims to explore the representation of the city branding of "Kampung Pesilat Indonesia" as sports tourism in the Madiun Regency. The method used in this study is in the form of a qualitative description. Data collection utilized observation techniques, in-depth interviews, and documentation studies. Data analysis used the MillesHuberman method which consisted of data reduction stage, data presentation stage, conclusion drawing stage, and verification. The results showed that: (1) The Madiun Regency Government promoted Pencak Silat sports tourism as a city branding, (2) The symbol and slogan "Kampung Pesilat Indonesia" is a visual representation of the diversity of Pencak Silat schools in Madiun Regency as an image of the city based on its regional potential, (3) The brand identity of the Kampung Pesilat Festival is one of the attractions for the city branding of Madiun Regency through the visual elements of the Pencak Silat sporting event.
\end{abstract}

Keywords: City branding, Pencak Silat, Sport Tourism

\section{Introduction}

Globalization is unavoidable. In an era, such as today, humans are required to develop to adapt. Not only humans, but an area also needs to make changes to maintain its existence. It is undeniable that today's competition is increasingly competitive. Competition is not only between companies but also between regions, countries, provinces, and cities. The era of globalization requires a city to manage the city's image and make that image a commodity, competing to be the best (Wahyudin \& Erlandia, 2018). Thus, competitiveness is the main key to being successful and surviving in the current era of globalization.

The era of globalization has made a city compete with each other, especially attracting tourists and investors (Isnaini \& Muktiali, 2015). The current development of globalization encourages the region to build an image that gives its own value to introduce and promote the region widely. For this reason, every local government seeks to use a marketing strategy through city branding. City branding is an identity, symbol, logo, or brand attached to an area. City branding is an appropriate means of communication to form a city image based on the potential of the area (Merrilees et al., 2012). City branding is also a means to achieve a competitive advantage to increase investment and tourism and also as a differentiating factor with other regions (Prayag, 2010). So that nowadays city branding has become an important tool applied by the government to increase competitiveness between regions.

The tourism sector has become one of the largest industries in the world. Tourism is an important and integral aspect of the country's development strategy (Utami, 2016). As an industrial activity, the tourism sector has an important role in economic, socio-cultural, and environmental development. The tourism sector is a sector that can support regional economic growth if it is managed properly and sustainably (Dinata, 2015). Tourism as one of the service and service industry activities is expected to contribute to the 


\section{Toton Aristono et. al/ The Representation of the City Branding of "Kampung Pesilat Indonesia" As Sports Tourism in the Madiun Regency}

country's foreign exchange earnings and can open up new jobs. Tourism is a different concept, from being only a release from saturation to being a livelihood for tourism actors (Sulton et al., 2020).

The tourism industry is one of the most important aspects of the country's economic development (Sadi, 2018). The development of tourism in a country will encourage acceleration in the economic sector. This is because tourism activities create demand in terms of consumption and investment which will trigger production and service activities (Ika, 2016). The development of the tourism industry in the region plays a role in developing the economy of the local community. Many benefits are felt by the local communities whether economically, socially, and culturally.

Today, there are a lot of efforts to develop and promote tourism potential in various regions in Indonesia, one of which is through sports tourism. Sports tourism is a new paradigm in the development of tourism and sports in Indonesia. Sports tourism is very likely to develop in Indonesia because the potential for sports tourism in Indonesia has many competitive advantages in offering tourist attractions. The development of tourist areas is expected to be able to encourage both economic potential and conservation efforts (Widodo, 2016). The development of sports tourism also needs serious attention to be able to create an advanced society (Priyono, 2012).

Indonesia is a country that has diverse cultural patterns and is spread throughout the country. One of the patterns and cultural diversity is reflected in the sport of Pencak Silat. Pencak Silat is one of the original cultures of the nation that was evolved in line with the history of its people's development. The rapid growth of Pencak Silat illustrates the magnitude of the cultural diversity that exists in Indonesia. In addition, Pencak Silat also influences the social order.

Madiun Regency is one of the potential areas for the development of sports tourism. It is one of the regions in Indonesia that is closely related to the martial art of Pencak Silat. Pencak Silat has the potential to be developed as a sports tourism attraction. There are at least 14 schools of Pencak Silat in Madiun which have a large enough mass and are scattered in several areas. Every year, thousands of Pencak Silat school members come to the regency to carry out various activities. Despite the fact that many members of the Pencak Silat schools have come, there has been no impact on Regional Original Income (ROI). The impact of the influence of ROI will provide a source for the government in creating all of its needs, this is to provide a stimulus for other regions to compete to be the best in the current era of regional autonomy (Rani, 2014).

In the era of regional autonomy, each region competes in regulating and developing its respective regions (Pratama, 2016). With its regional autonomy status, the Madiun Regency Government has the authority to develop its regional potential. One of them is tourism potential that will have an impact on the community. Madiun is very rich in potential for culture, arts, sports, and tourism. Pencak silat has tourism potential to increase the pace of the economy. One of the ways to develop economic potential is through Micro, Small and Medium Enterprises (Rusdarti, 2010). Pencak silat in Madiun Regency has the ability to develop Micro, Small and Medium Enterprises if managed properly. The development of tourism requires the active role of various parties, both from the government, tourism managers, and the local community. The central government to local governments at the lowest level has a role in regulating, fostering, and developing (Sadi, 2018).

Madiun Regency has a lot of potentials that can be developed, especially in the tourism sector. One of the efforts made by the Madiun Regency Government to develop tourism potential and promote the region is through city branding. The tourism potential seems to be used as a reference to form the city branding of the regency. City branding is a marketing activity to promote a positive image of a tourist destination as an attraction to influence consumer decisions to visit it (Wandari, 2014). The concept of city branding itself is a new thing for Madiun Regency. In this case, the Madiun Government raised the potential of the martial art of Pencak Silat as a city branding. The choice of Pencak Silat is because Madiun Regency is identical with the potential of the martial art of Pencak Silat and this is a distinguishing value that is not found in other areas. The slogan "Kampung Pesilat Indonesia" was launched by the Madiun Regency Government in 2018 which focuses on imaging the city to increase tourist visits, especially sports tourism. Tourism potential can be developed as attractively as possible so that later it can represent the branding that the city itself wants to form (Larasati and Nazaruddin, 2016). These potentials will later have a positive impact on regional economic development and the level of welfare of local communiti. 


\title{
Toton Aristono et. al/ The Representation of the City Branding of "Kampung Pesilat Indonesia" As Sports Tourism in the Madiun Regency
}

\begin{abstract}
Methods
This study used a qualitative descriptive research method with a single case study approach that is interpretive. Whereas the case studies required a description of the method through literature review and indepth interviews to understand experiences, perspectives, and views of people in certain circumstances (Denzin \& Lincoln, 2011). Qualitative methods were used to obtain detailed information from sources as a guide for researchers to process data to produce objective research. This research was carried out from March to May 2021 with informants from the Madiun Regency Youth and Sports Tourism Office.

The data collecting process in this study utilized observation techniques, in-depth interviews, and documentation studies. The observation technique was carried out by researchers to determine the initial conditions by making direct observations of the city branding application process and the impact felt by the community. Furthermore, researchers conducted interviews with informants to obtain information and explore in-depth and multidimensional data from the informants. Documentation study in the form of city branding images installed in various promotional media used by the Madiun Regency Government. The data analysis technique uses flow model data analysis with data reduction stages, data presentation, and conclusion drawing.
\end{abstract}

\section{Results and Discussion}

Madiun Regency is one of the conservation areas for the original Indonesian culture, namely Pencak Silat. The regency has a long history in the development of Pencak Silat in Indonesia. The history of the Pencak Silat's development in Madiun Regency began in the 1900sand is still preserved until now. These forms of preservation include the existence of various original Pencak Silat organizations from Madiun Regency which helped shape the flow of Pencak Silat in Indonesia. Like two sides of a coin that are intertwined, Pencak Silat is an inseparable part of Madiun Regency.

Madiun Regency as one of the regions in Indonesia realizes that changes must be made inorder to be able to compete in an increasingly globalized environment. For this reason, it is very necessary to differentiate the new potentials that can be of special value for the Madiun Regency.To show potential as an important aspect in the development of a region, it is necessary to have the right facilities for the regency to build a positive image. One of them is by raising Pencak Silat as a city branding. In this modern era, it is time for Pencak Silat in Madiun to be known from another point of view so that Pencak Silat is not only seen from the sports aspect, but also other aspects.

Madiun Regency has various tourism potentials, including cultural, sports, historical, and artistic sectors. However, currently, the Madiun Regency Government is making city branding through the sports sector by promoting Pencak Silat. The sport of Pencak Silat has taken root in a characteristic in the regency where there is martial arts training ground in almost every neighborhood. Pencak Silat is believed to have enough power to be a special attraction so that in 2018, Madiun Regency made a city branding "Kabupaten Madiun Kampung Pesilat Indonesia". The number of Pencak Silat schools can be a potential for Madiun through sports tourism. This city branding will have an impact on the community, especially tourism enthusiasts and local entrepreneurs. Making city branding about the sport of Pencak Silat is not merely to increase regional income. However, making this branding also functions to introduce the Madiun Regency to be better known by the public and to differentiate it from other regions by raising the characteristics possessed by Madiun Regency.

In order to develop city branding, the Government of Madiun Regency made various efforts such as through visualization of logo and slogan. These logo and slogan carry the concept of balance in the diversity of society with noble character. The logo and slogan are then used on all promotional media, both printed and electronic media. The government also held a sports event titled the Festival Kampung Pesilat Indonesia which was a multi-event with Pencak Silat theme. The goal is to socialize the city branding "Kampung Pesilat Indonesia" to local communities, foreign tourists, and investors. 


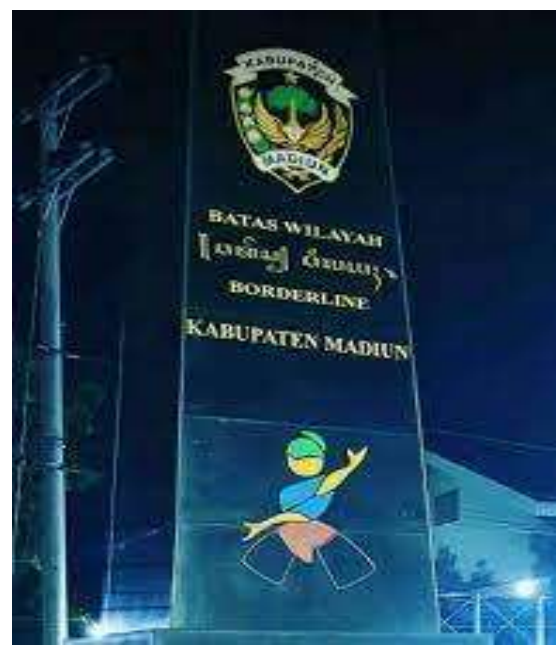

Figure 1. Landmark of the Pesilat village logo

\section{The Logo}

The logo concept of "Kabupaten Madiun Kampung Pesilat Indonesia" is a symbol of vigilance, independence, balance and diversity of people with noble character. This logo incorporates all of the values and goals that the government wishes to achieve in order to make Madiun Regency a tourist destination for the sport of pencak silat. The logo, which is in the shape of a fighter with different colors, represents the diversity of pencak silat, which grows and develops with its own characteristics. This diversity has become its own color and attraction for the regency. This is stated in the logo element, which depicts a fighter in a stance wearing a headband with his hands up and down. The headband symbolizes a noble society. The position of the hands represents alertness. The batik cloth symbolizes the spirit of preserving culture with local wisdom and the position of the stance depicts independence. There are five colors on the Pesilat logo which symbolize the diversity of the Pencak Silat schools in Madiun Regency. The green color symbolizes generosity, courtesy, and hospitality, the yellow color symbolizes friendship, the blue color symbolizes unity, the brown color symbolizes simplicity and the blackcolor symbolizes strength and firmness.

\section{The Slogan}

The slogan of "Kampung Pesilat Indonesia" is the branding chosen by the Madiun Regency Government in promoting the potential of Pencak Silat as sports tourism. This slogan was chosen because Madiun Regency has always been known for the sport of pencak silat but does not yet have a brand name for introducing the sport. The choice of this slogan is also considered capable of showing that Madiun has various pencak silat schools that were born and developed in the area. There are at least 14 martial arts colleges in Madiun. There are at least 14 martial arts schools in Madiun. Through this slogan, the Madiun Government wants to change the new paradigm of Pencak Silat among the people. Kampung Pesilat Indoensia is used as a slogan to unite all pencak silat schools in establishing Madiun Regency as a center for pencak silat development in Indonesia. The existence of the slogan "Kampung Pesilat Indonesia" is also very helpful in introducing the potential of the Madiun Regency in terms of sports tourism. Moreover, the slogan is a selling point to attract investors so that it can have impacts on various sectors in Madiun Regency.

\section{City Branding Through Pencak Silat Events}

In order to develop sports tourism in Madiun Regency, the government held an event entitled the Festival Kampung Pesilat Indonesia. The Festival Kampung Pesilat Indonesia is an interesting and strategic blend of Pencak Silat sports performances with tourism promotion. Festival Kampung Pesilat is a Pencak Silat martial arts event which is also an attraction for Madiun Regency as a sports tourism destination. This event is an annual routine agenda that is held to promote Madiun and also preserve the culture of Pencak Silat. This festival is a multi- event that contains various Pencak Silat activities such as seminars and workshops of Pencak Silat, Pencak Silat championships, parades of warriors and fighters, and festivals of the arts of Pencak Silat. The existence of a Festival Kampung Pesilat Indonesia event every year can attractattention in 


\section{Toton Aristono et. al/ The Representation of the City Branding of "Kampung Pesilat Indonesia" As Sports Tourism in the Madiun Regency}

the eyes of public because the fighters display their works in various ways. With high public interest, it will have a positive impact on increasing the tourism sector, especially sports tourism.

\section{Indonesian Fighter Village}

Making a brand in an area, both within the scope of city and district government is currently very much needed. The existence of a brand that is built can help an area to introduce and make the name of a company or area rise in the eyes of the public, even with a brand it can add selling value and attract investors or tourists to come and visit the area. It is widely known that a brand does not only contain a logo, name or term of a product, but with a brand it can also function as a differentiator between brands owned by one region and another. Through a brand, a product can also be easily remembered by the public because of the characteristics displayed in a brand, be it in terms of the slogan, the name raised, the logo, or the color chosen.

Madiun Regency has various tourism potentials, ranging from the cultural, recreational, historical or artistic sectors. However, currently the Madiun Regency Government wants to raise the potential of the cultural sector. Making branding about this culture is not merely to increase regional income. However, the creation of branding about this culture is also used to introduce the Madiun Regency area to be better known by the public and to differentiate it from other regions by raising the characteristics possessed by Madiun Regency. The idea of adopting cultural tourism is reviewed or seen from the current high level of interest in cultural tourism, especially for tourists outside the region or foreign tourists as well as bringing in new investors to the region.

Currently, Madiun Regency through the Youth and Sports Tourism Office is promoting and introducing its region to tourists by lifting its cultural potential. One of them is the culture of pencak silat. Pencak silat is a native Indonesian culture which in its development has a very distinctive diversity in each region and every province. In the course of the development of pencak silat in East Java Province has a long history, starting from the royal period to the present. The development of pencak silat in East Java is not only about pencak silat from a sporting perspective, but also from other aspects. One of the districts in East Java Province that is closely related to pencak silat is Madiun Regency.

Today, the martial art of pencak silat has taken root into a characteristic in Madiun Regency. Where almost every area has a martial arts training ground. The interest of the people of Madiun Regency in pencak silat which systematically makes pencak silat is still preserved and exists. Pencak silat is believed to have enough power to become a special attraction, especially for people outside Madiun Regency.

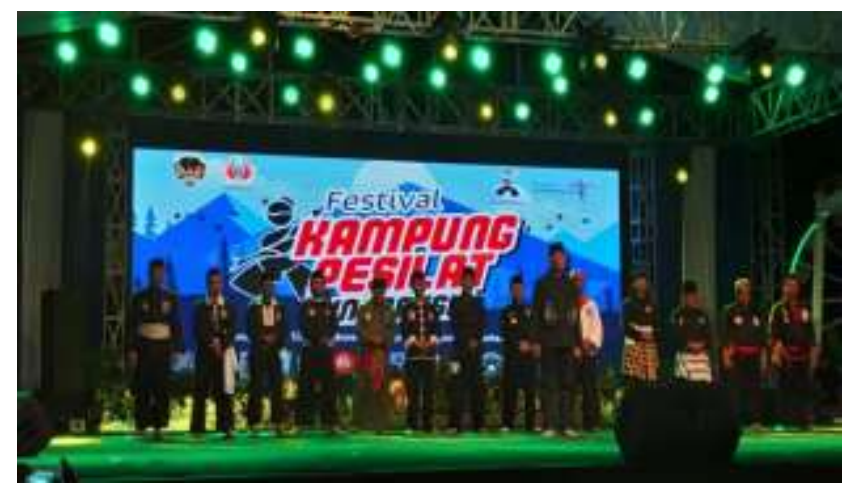

Figure 2. Pesilat village festival

From the existence of the cultural potential of pencak silat, there must be historical values or unique traditions that can be appointed to be the attraction of Madiun Regency. For example, there is the tradition of Suran Agung which is often carried out every Suro month or commonly called an activity in welcoming the 1st month of Muharram. The suran agung tradition is not only used to welcome and commemorate the 1st month of muharram, suran agung is also used by fighters to commemorate the birthday of their silat college, gathering between members, visiting the graves of college elders, or fostering the spirituality of silat members.

Madiun Regency has at least 14 pencak silat colleges, eight of which were born in Madiun. The impact of the many pencak silat colleges in Madiun Regency not only has a positive impact but also has some negative 


\section{Toton Aristono et. al/ The Representation of the City Branding of "Kampung Pesilat Indonesia" As Sports Tourism in the Madiun Regency}

impacts. The phenomenon of violence between pencak silat universities in Madiun Regency has become a study among the public. Friction between fellow members of the pencak silat college to the point of conflict often occurs almost every year and not a few in the conflict claimed victims both materially and morally. In addition, the presence of conflict is also increasingly causing anxiety and discomfort from various aspects of life in the community. These incidents and events certainly made public opinion unfavorable to the fighters in Madiun, besides that they also had a bad impact on the image of Madiun Regency which was considered a terrible, unfriendly, or safe area. It also has a negative impact on the tourism sector in Madiun. Because with the Suran Agung activity, people outside the Madiun area are afraid and reluctant to visit or come to the Madiun area, precisely in the Regency when the month of Muharram approaches.

Conditions like this can harm Madiun Regency as an area that has a variety of martial arts cultures that can be utilized and preserved. This is the responsibility of the regional government as a state apparatus that has the rights and duties as the organizer of an area and protects the community to create a sense of security, comfort and develop better. Local governments take part in resolving conflicts in their territory.

This was stated by the Deputy Regent of Madiun Regency, namely Mr. Hery Wuryanto: “... So actually the branding of the fighter village is nothing but to unite the people of Madiun Regency. Because we can see from all the teachings of pencak silat that it is a virtuous teaching, but on the surface it is only visible in the community, fights and friction between universities. Maybe this is not well organized or there is a lack of support so that the government is here to create that Madiun Regency is a fighter village, even though there are many fighters and many fighters, the safe condition according to the vision and mission of Madiun Regency can be realized" (Interview with Mr. Hery Wuryanto on Tuesday, 11 May 2021 at 09:05 am).

The Chairperson of IPSI Madiun Regency, Mr. P.W Widodo also agreed with this opinion: “...At first, the branding of the fighter village appeared during a gathering of pencak silat colleges in Madiun which was attended by the East Java Regional Police Chief at that time and all pencak silat colleges in East Java. The activity was carried out in order to provide a forum and convey the aspirations of each university, including discussing the situation and conditions in Madiun during the suroan. The meeting resulted in an agreement to form the Madiun Pencak Silat Association, which has the Madiun Pesilat Village branding. As time goes by, the current regent wants to raise the pencak silat culture as an icon of Madiun Regency so that IPSI as the umbrella sector has proposed the name of Madiun Regency as Indonesian Pesilat Village" (Interview with Mr. PW Widodo on Thursday, April 22, 2021 at 13: 18 pm).

The emergence of this fighter branding was stated during a gathering of pencak silat colleges in Madiun which was attended by the East Java Police Chief and all pencak silat colleges in East Java. This is because there are often riots and clashes that create a stigma or negative mindset about pencak silat and Madiun Regency among the community. This meeting resulted in an agreement to form the Madiun Pencak Silat Association which eventually resulted in the name Madiun Kampung Pesilat. This is also desired by the Regent by elevating the culture of pencak silat as an icon of Madiun Regency. As the field that oversees Pencak Silat in Madiun Regency, IPSI Madiun Regency has proposed the name of Madiun Regency, Indonesian Pesilat Village.

The Madiun Regency Government as an executive agency has the task and function to overcome the problems that exist in its territory assisted by related agencies or agencies. The government cooperates with other agencies/institutions to reduce and resolve conflicts between fellow members of the pencak silat college. The government together with other agencies/institutions have their respective roles in preventing and resolving conflicts related to the pencak silat college. One of the efforts of the Madiun Regency government is to form the Madiun Pencak Silat Association.

\section{Conclusion}

The city branding of "Kabupaten Madiun Kampung Pesilat Indonesia" forms a new paradigm of people's views about Pencak Silat in Madiun Regency as sports tourism. Sports tourism, especially Pencak Silat, has a positive influence on tourism development in Madiun Regency because it has a significant contribution from the economic sector. One of the efforts made by the Madiun Government in the context of developing sports tourism is through the brand name "Kampung Pesilat Indonesia". The form of implementation of the city branding is through the concept of symbols and slogans. The concept of logo and slogans is a representation of the people's visual characteristics in Madiun Regency. It can be seen how the 


\section{Toton Aristono et. al/ The Representation of the City Branding of "Kampung Pesilat Indonesia" As}

Sports Tourism in the Madiun Regency

logo and slogans reflect the diversity of Pencak Silat in the Madiun Regency. The concept of the fighter is considered capable of describing the potential that exists in the regency. The Festival Kampung Pesilat Indonesia event is one of the efforts to accelerate the city branding of Madiun Regency as sports tourism. Lastly, Madiun Regency as the organizer makes the image of the region as a center for the development and tourism of pencak silat in Indonesia deserves to be pinned.

\section{References}

1. B. Priyono. 2012. Pengembangan Pembangunan Industri Keolahragaan berdasarkan Pendekatan Pengaturan Manajemen Pengelolaan Kegiatan Olahraga. Jurnal Media Ilmu Keolahragaan Indonesia 2(2):112-123.

2. Denzin, Norman K., \& Yvonna S. Lincoln. (2011). The Sage Handbook of Qualitative Research. Sage.

3. Dinata, Mussadum. 2015. Pengaruh Pengembangan Kawasan Wisata Geopark Merangin terhadap Kesejahteraan Masyarakat Desa Air Batu. Biro Penerbit Planologi Undip 11(3):327-338.

4. Isnaini, N. W., \& Muktiali, M. (2015). Pengaruh Keberadaan Desa Wisata Samiran Terhadap Perubahan Lahan, Ekonomi, Sosial dan Lingkungan. Jurnal Teknik PWK UNDIP, 4(3), 389-404.

5. Larasati, Dyas., Nazaruddin, M. 2016. Potensi Wisata Dalam Pembentukan City Branding Kota Pekanbaru. Jurnal Komunikasi. Vol.10, No.2.

6. Merrilees, B., Miller, D., \& Herington, C. (2012). European Journal of Marketing Multiple stakeholders and multiple city brand meanings. European Journal of Marketing Journal of Place Management and Development European Journal of Marketing Journal of Place Management and Development Iss Downloaded by UNIVERSITY OF MALTA At, 46810(11), 1032-1047.

7. Muktiali, Mohammad. 2012. Kaji Banding City Branding Kota Semarang dengan Kota di Indonesia (Solo dan Surabaya) dan Kota Dunia (Kota Amsterdam). Semarang : Universitas Diponegoro.

8. Pratama, E. H. 2016. Evaluasi Branding Jogja Never Ending Asia sebagai Strategi Memasarkan Daerah di Era Otonomi. Jurnal Ilmu Sosial MAHAKAM, 5(1),1-20.

9. Prayag, G. (2010). Brand image assessment: International visitors' perceptions of Cape Town. Marketing Intelligence and Planning, 28(4), 462-485. https://doi.org/10.1108/02634501011053577

10. Rani, D. P. M. 2014. Pengembangan Potensi Pariwisata Kabupaten Sumenep, Madura, Jawa Timur (Studi Kasus: Pantai Lombang). Jurnal Politik Muda 3(3); 412-421.

11. Rusdarti. 2010. Potensi Ekonomi Daerah dalam Mengembangkan UKM Unggul di Kabupaten Semarang. JEJAK. 3(2); 143-155.

12. R. W. Widodo. 2016. Analisis Potensi Pariwisata Olahraga di Kabupaten Wonosobo. Skripsi. Jurusan Ilmu Keolahragaan, Universitas Negeri Semarang.

13. Sadi. 2018. Peran Pemerintah terhadap Pengembangan Olahraga Pariwisata untuk Peningkatan Perekonomian Masyarakat. Prosiding Seminar Nasional IPTEK Olahraga, ISSN 2622-0156.

14. Sulton, Yulia Wulansari, B., \& Sinta Utami, P. (2020). Wayang Golek Reog Ponorogo: The Acculturation of Indonesian Culture As Patriotism Character Education Learning Medium to Early Age Children. KnE Social Sciences. https://doi.org/10.18502/kss.v4i4.6494

15. T. Ika W. 2016. Pengaruh Pendapatan Sektor Pariwisata terhadap Pertumbuhan Ekonomi Kota Makassar. Skripsi. Jurusan Ilmu Ekonomi Fakultas Ekonomi dan Bisnis Islam UIN Alauddin Makassar.

16. Utami., et,al. 2016. Analisis Potensi Objek Wisata Pantai Pagatan di Kecamatan Kusan Hilir Kabupaten Tanah Bumbu. Jurnal Pendidikan Geografi 3(5),1-14.

17. Wahyudin, U., \& Erlandia, D. R. (2018). Peran humas pemerintah dalam pemasaran city branding melalui media massa. Jurnal Common, 2(2). https://doi.org/10.34010/common.v2i2.1192

18. Wandari., et,al. 2014. Pengaruh City Branding Shining Batu Terhadap Minat Berkunjung Wisatawan Ke Kota Batu. Jurnal Administrasi Bisnis, Vol. 16 No. 1. 